\title{
Tubulin Gamma-2 Chain
}

National Cancer Institute

\section{Source}

National Cancer Institute. Tubulin Gamma-2 Chain. NCI Thesaurus. Code C38490.

Tubulin gamma-2 chain (451 aa, $\sim 51 \mathrm{kDa}$ ) is encoded by the human TUBG2 gene. This protein is involved in the assembly of microtubules and microtubule organizing centers (MTOCs). 